\title{
КОМПАРАТИВИСТСКИЙ ПОДХОД К АНАЛИЗУ ПИФОВ В СИСТЕМЕ КОЛЛЕКТИВНОГО ИНВЕСТИРОВАНИЯ
}

\author{
(c) 2020 Ермолаев Константин Николаевич \\ доктор экономических наук, профессор \\ Самарский государственный экономический университет, Россия, Самара \\ E-mail:ermolaevkn@yandex.ru \\ (c) 2020 Недорезова Елена Сергеевна \\ кандидат экономических наук, доцент \\ Самарский государственный экономический университет, Россия, Самара \\ E-mail: nedlen63@yandex.ru
}

Коллективное инвестирование представляет собой организацию инвестиционных вложений, при которой под управлением профессионального управляющего объединяются денежные средства отдельных инвесторов с целью их последующего прибыльного размещения. Паевые инвестиционные фонды (ПИФ), как инструмент коллективного инвестирования, являются сравнительно новой, перспективной формой инвестирования денежных средств российскими инвесторами, в том числе не имеющими опыта в инвестировании, поскольку ПИФы являются доступным финансовым инструментом. Паевые инвестиционные фонды дают возможность приносить значительно более высокие доходы инвесторам (по сравнению с доходностью вложений в банковские депозиты). В статье проведена характеристика институтов инвестирования и сравнение их по основным параметрам, а также характеристика инструментов инвестирования ПИФ, АИФ и НПФ.

Ключевые слова: паевые инвестиционные фонды, обязательное пенсионное страхование, инструменты инвестирования.

В настоящее время существует три инструмента коллективного инвестирования: паевые инвестиционные фонды, акционерные инвестиционные фонды (АИФ) и негосударственные пенсионные фонды (НПФ).

ПИФ, АИФ и НПФ дают возможность инвесторам вкладывать свой капитал в такие инвестиционные инструменты, приобрести которые самостоятельно достаточно проблематично. При этом инвестиционные инструменты у каждого института коллективного инвестирования различаются, следовательно, необходимо подробно рассмотреть инструменты коллективных институтов, выявить их сходства и различия, и по итогу определить оптимальный институт коллективного инвестирования для частного инвестора.

НПФ - это организации, которые созданы для сбора пенсионных взносов, инвестирования собранных денежных средств и выплаты из них дополнительных пенсий участникам. Приоритетной сферой деятельности НПФ является инвестирование денежных средств с целью увеличения пенсионных накоплений своих участников. НПФ, который осуществляет деятельность по

обязательному пенсионному страхованию, не вправе самостоятельно инвестировать средства пенсионных накоплений, а обязан передавать их в доверительное управление управляющей компании.

НПФ могут создаваться в форме акционерного общества. Фонд вправе выпускать только обыкновенные акции. Фонд не вправе осуществлять операции с векселями и выдавать займы. Кроме того, первые дивиденды по акциям будут выплачиваться через пять лет после регистрации НПФ как акционерной организации [1].

Имущество фонда подразделяется на собственные средства, пенсионные резервы и пенсионные накопления. НПФ отвечает перед вкладчиками всем принадлежащим ему имуществом: уставным капиталом и страховым резервом. Основными инструментами инвестирования НПФ являются договор негосударственного пенсионного обеспечения.

АИФ представляет собой открытое акционерное общество, основные средства которого передаются управляющей компании для инвестирования, а относительно небольшая часть используется на расходы, связанные с функци- 
онированием.

Деятельность АИФа является исключительной, осуществляется на основании лицензии Банка России, иные виды предпринимательской деятельности он осуществлять не может. Устав АИФ обязательно должен содержать положение о том, что исключительным предметом деятельности этого фонда является инвестирование в имущество, подразделяющееся на: инвестиционные резервы (имущество, предназначенное для инвестирования), или активы (обязательны к передаче в доверительное управление управляющей компании); имущество, предназначенное для обеспечения деятельности органов управления и иных органов АИФ.

Основным инвестиционным инструментом АИФ являются акции.

Так как АИФ может быть создан только в форме AO, то он платит налоги по общим основаниям, наряду с остальными акционерными обществами [2].

Рассмотрим характеристику институтов инвестирования и сравнение их по основным параметрам [3], а также характеристику инструментов инвестирования ПИФ, АИФ и НПФ (табл. 1).

Исходя из данных таблицы, можно сделать следующие выводы.

НПФ представляет собой альтернативу госу- дарственного пенсионного фонда. Эти организации позволяют вкладчикам открыть накопительную часть пенсии задолго до наступления пенсионного возраста.

НПФ специализируются на долгосрочном инвестировании. НПФ может вкладывать средства только в ограниченное число активов с минимальным риском - депозиты, облигации и некоторые акции. Поэтому доходность НПФ по сравнению с другими формами коллективного инвестирования невелика. Основной целью вкладчиков НПФ является обеспечение для себя достойной старости. Следовательно, стратегия инвестирования НПФ разработана таким образом, чтобы вложенные средства стали приносить доход спустя несколько лет.

АИФ как юридическое лицо представляет собой акционерное общество (АО), в то время как ПИФ представляет собой обособленный имущественный комплекс без образования юридического лица. А это значит, что финансовые возможности инвестора в акционерном фонде эквивалентны количеству его акций, в ПИФах финансовые возможности инвестора ограничены только типом паевого инвестиционного фонда.

Средства ПИФ могут быть инвестированы в различные объекты инвестирования в зависи-

Таблица 1. Сравнение институтов коллективного инвестирования в России.

\begin{tabular}{|c|c|c|c|}
\hline Критерий & ПИФ & АИФ & НПФ \\
\hline $\begin{array}{c}\text { Организационная } \\
\text { форма }\end{array}$ & $\begin{array}{c}\text { Имущественный ком- } \\
\text { плекс без образования } \\
\text { юр. лица }\end{array}$ & $\mathrm{OAO}$ & $\mathrm{AO}$ \\
\hline Цель создания & Получение прибыли & Получение прибыли & $\begin{array}{c}\text { Организация эффектив- } \\
\text { ного инвестирования } \\
\text { пенсионных накоплений }\end{array}$ \\
\hline $\begin{array}{l}\text { Документ, который вы- } \\
\text { дается при вступлении }\end{array}$ & Инвестиционный пай & $\begin{array}{c}\text { Обыкновенная именная } \\
\text { акция } \\
\end{array}$ & Пенсионный договор \\
\hline $\begin{array}{c}\text { Является ли он ценной } \\
\text { бумагой } \\
\end{array}$ & Да & Да & Нет \\
\hline $\begin{array}{c}\text { Объекты, передаваемые } \\
\text { в управление }\end{array}$ & $\begin{array}{c}\text { Денежные средства и } \\
\text { иное имущество }\end{array}$ & $\begin{array}{c}\text { Денежные средства и } \\
\text { иное предусмотренное } \\
\text { имущество }\end{array}$ & Денежные средства \\
\hline $\begin{array}{c}\text { Передача прав участия } \\
\text { (за исключением случая } \\
\text { наследования) }\end{array}$ & Продажа пая/погашение & Продажа акции & Нет \\
\hline $\begin{array}{c}\text { Основной законода- } \\
\text { тельный акт, регулиру- } \\
\text { ющий деятельность }\end{array}$ & $\begin{array}{c}\text { 156-ФЗ «Об инвестицион- } \\
\text { ных фондах» }\end{array}$ & $\begin{array}{c}\text { 156-ФЗ «Об инвестицион- } \\
\text { ных фондах» }\end{array}$ & $\begin{array}{l}\text { 72-Ф3 «О негосударствен- } \\
\text { ных пенсионных фондах» }\end{array}$ \\
\hline Особенности & $\begin{array}{c}\text { Средний уровень риска, } \\
\text { разнообразие форм и } \\
\text { видов инвестирования }\end{array}$ & $\begin{array}{c}\text { Возможность эмиссии } \\
\text { ценных бумаг, средний } \\
\text { уровень риска }\end{array}$ & $\begin{array}{c}\text { Долгосрочные инвести- } \\
\text { ции, низкий уровень } \\
\text { риска, сильное гос. регу- } \\
\text { лирование }\end{array}$ \\
\hline
\end{tabular}


мости от категории ПИФа. Всего законодательство предусматривает 16 различных категорий классификации ПИФов по объектам инвестирования. ПИФы позволяют инвестировать и в высоколиквидные активы, и в низколиквидные активы с высоким риском.

На основании сравнительной характеристики (табл. 2) можно сделать следующие выводы, и определить оптимальный институт коллективного инвестирования для частного инвестора.

Негосударственный пенсионный фонд создан с целью формирования средств пенсионных накоплений. Порядок функционирования НПФ строго регламентируется нормами действующего законодательства, что не позволяет им осуществлять рискованные инвестиции. Также следует отметить, что НПФ должен обладать существенной страховой суммой, которая в случае банкротства будет потрачена на выплаты вкладчикам.

Роль пенсионных институтов начинает от- чётливо реализоваться только по достижении их пенсионными резервами значительных объёмов. Для того чтобы непосредственно частному инвестору осуществить инвестирование на финансовом рынке, необходимо обратиться в АИФ или ПИФ, которые в свою очередь имеют несколько существенных отличий.

Учитывая, что нормативными правовыми актами не регламентированы признаки риска, с которым может столкнуться инвестор при покупке акций фонда [4], то акционерный фонд будет рассматриваться как часть акционерного общества, где «акционеры не отвечают по обязательствам общества и несут риск убытков, связанных с его деятельностью, в пределах стоимости принадлежащих им акций». В этом заключается основное отличие ПИФов от АИФов: риск ПИФов состоит в убытках от изменения рыночной стоимости имущества, а риск АИФов заключается в деятельности фонда и ограничен стоимостью акций [5].

Таблица 2. Сравнительная характеристика инструментов инвестирования НПФ, АИФ и ПИФ

\begin{tabular}{|c|c|}
\hline & Характеристика инструмента \\
\hline 胥 & $\begin{array}{l}\text { - Бездокументарная ценная бумага. } \\
\text { - Учёт прав на инвестиционные паи осуществляется на лицевых счётах в реестре владельцев } \\
\text { паёв. } \\
\text { - Пай не имеет номинальной стоимости. } \\
\text { - Когда инвестор становится пайщиком в фонде, он не покупает какое-то целое число паев, } \\
\text { а просто вносит в фонд любую сумму средств не ниже минимальной суммы, определенной } \\
\text { управляющей компанией для каждого фонда. } \\
\text { - Количество паёв, выдаваемых управляющей компанией фонда, зависит от типа фонда. }\end{array}$ \\
\hline 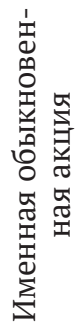 & $\begin{array}{l}\text { - Инвестор, приобретая акцию АИФа становится акционером фонда, и получает право рас- } \\
\text { пределять прибыль, получать дивиденды, а также право на участие в управлении АО. } \\
\text { - Акции АИФа можно купить на бирже. } \\
\text { - Неполная оплата акций при их размещении не допускается. } \\
\text { - Акционеры АИФ могут получать дивиденды по акциям. } \\
\text { - Прекращение деятельности АИФа может произойти только по решению общего собрания } \\
\text { акционеров. }\end{array}$ \\
\hline 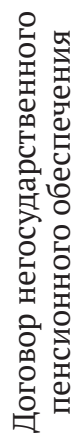 & $\begin{array}{l}\text { - Представляет собой соглашение между фондом и вкладчиком, в соответствии с которым } \\
\text { вкладчик уплачивает пенсионные взносы в фонд, а фонд выплачивает негосударственную } \\
\text { пенсию. } \\
\text { - Позволяет получить выплаты при наступлении пенсионного возраста, в том числе при } \\
\text { отсутствии страхового стажа. } \\
\text { - Позволяет досрочное снятие пенсионных накоплений. } \\
\text { - Вкладчиками фонда могут быть физические и юридические лица. } \\
\text { - Договор может быть расторгнут в одностороннем порядке по желанию вкладчика. } \\
\text { - Срок действия договора равен периоду выполнения сторонами обязательств. }\end{array}$ \\
\hline
\end{tabular}


Также существенным отличием ПИФов от АИФов является двойное налогообложение, понижающее привлекательность акционерных фондов перед инвесторами. Изначально АИФы платят налог на прибыль, полученную в ходе деятельности по ставке $20 \%$, а после, при распределении чистой прибыли в качестве дивидендов, акционеры уплачивают налог на дивиденды.

Таким образом, можно сделать вывод, что роль ПИФов заключается в том, что у частного инвестора существует возможность доступа к финансовым инвестициям путём аккумулирования денежных средств инвесторов и их даль- нейшем вложением в инвестиционно-привлекательные объекты, обладающие потенциалом роста стоимости [6].

Резюмируя всё вышесказанное очевидно, что в настоящее время паевые инвестиционные фонды наиболее эффективно решают задачи сбережения и капитализации средств частных инвесторов по сравнению с другими институтами коллективного инвестирования. Следовательно, паевые инвестиционные фонды можно считать оптимальным институтом коллективного инвестирования с целью получения дохода.

\section{Библиографический список}

1. Ф3 от 07.05.1998 N75-Ф3 (ред. от 26.07.2017) «О негосударственных пенсионных фондах». [Электронный pecypc].- Режим доступа. - URL: http://www.consultant.ru/document/cons_doc_LAW_18626/ (дата обращения 22.04.2019).

2. Мишина М.С., Михайлов А.М. Особенности налогообложения операций с ценными бумагами //Наука XX1 века: актуальные направления развития. 2019. № 2-2. С. 27-31.

3. Аганина Р.Н., Андреев В.К., Андреева Л.В. Предпринимательское право. Правовое сопровождение бизнеса. // Отв. ред. И.В. Ершова.- Москва, 2017. 848 с.

4. Кузнецов К.В., Михайлов А.М. Составляющие механизма регулирования риска ликвидности акций //Управление экономическими системами: электронный научный журнал. 2017. № 10 (104). С. 2.

5. Капитан М., Барановский Д. ПИФы: современный подход к управлению деньгами.- Санкт-Петербург, 2015.- $240 \mathrm{c}$.

6. Konovalova, M.Y., Kuzmina, O.Y., Mikhaylov, A.M., Levchenko, L.V., Salomatina, S.Y.//The management of investment portfolios (2019) TEM Journal, 8 (3), pp. 928-937. 